\title{
Description of Difficulties in Implementing The Assessment of Performance Aspects for Understanding Mathemathic Teachers at MTs Al Mustaqim Parepare
}

\author{
Vernita Sari \\ Mathematic Education \\ University of Muhammadiyah Parepare \\ Parepare, Indonesia \\ vernita_sari111186@yahoo.com
}

\begin{abstract}
Performance assessment needs to understand and implement by teachers so that the teachers can assess the skills aspects of their students well. However, some teachers have difficulties in implementing performance assessment includes mathematic teachers at MTs Al Mustaqim Parepare. The purpose of this research is to describe the difficulties of implementing performance assessment on understanding aspects of mathematic teachers at MTs Al Mustaqim Parepare. This research was qualitative research. The subjects of the study were two mathematic teachers of MTs Al-Mustaqim Parepare here in after called subject $1(\mathrm{H})$ and subject $2(\mathrm{~N})$. The focus of the research is to describe the difficulties teachers using the performance assessment on aspects of teachers' understanding of mathematic. For revealing the research data, this conducts tests and interviews to the subject of research. The data of research is validated by doing triangulation method. The Research of data is analyzed by (a) studying the subject data and comparing data to obtain for valid data, (b) reducing data by creating abstractions, (c) classifying and identifying the data to draw conclusions from the data. The result research shows that the difficulties for teachers, it is for understanding aspect about the assessment performance. For instance, (a) the subject $1(\mathrm{H})$ was difficult in understanding about the concept of assessment, (b) the subject $1(\mathrm{H})$ was difficult in understanding the assessment techniques so that it can be implemented, (c) subject $1(\mathrm{H})$ was difficult in understanding the types of assessment rubrics, and $(\mathrm{d})$ subject $2(\mathrm{~N})$ was difficult in understanding the concept of assessment.

Keywords: Difficulties, Performance Assessment, Teacher's Understanding
\end{abstract}

\section{INTRODUCTION}

One of the improving the quality of education is the curriculum reform. Curriculum evaluation is absolutely to assess the relevance of the curriculum to students in the context of a dramatically changing place.

The changing in the content of the standard elements of the curriculum of 2013 (Abidin, 2014) it makes the teachers who have been using traditional valuation 
should change its assessment that become authentic assessment, based on the demands of the curriculum. In the authentic assessment, it has many techniques in its implementation one of them is performance assessment (performance assessment). The assessment of this performance is essentially an assessment conducted to assess the competence of students' skills. According to Permendikbud No. 66 years, 2013 (Majid) it explained that educators to assess the competence skills through performance assessment, such as the assessment demands the students to demonstrate a certain competence by using the practice test, project, and portfolio assessment.

Based on the explanation before it gives us an idea that the performance assessment is very good in mathematic learning for performance assessment and it can facilitate teachers to assess aspects of the student's skills. Performance assessment is not a new thing for some teachers in Indonesia because some teachers have assessed this model. Only in general teachers are more familiar with the assessment of traditional models. Because most of teachers feel unfamiliar with this performance assessment, so when the teachers want to apply this judgment they faced for many obstacles or difficulties in doing so. In addition, most of teachers also do not really understand what the essence of performance assessment is.

It is also felt by mathematic teachers at MTs Al Mustaqim Parepare that have assessed the performance, some of information obtained by researcher from mathematic teachers in the schools and also through a variety of reading material is obtained that one of the difficulties teachers to apply performance assessment was the teacher actually do not understand what it's performance assessment. Then, Meutia (2013) states that teachers' knowledge related assessments showed good category $33 \%$ and $67 \%$. The type assessment which appears in the form of $29 \%$ which selected the response selection, description or essay 43\%, 21\% performance, as well as interviews or personal communication $7 \%$.

Based on those problems, the researcher did her research under title of "Description of Difficulties in Implementing the Assessment of Performance Aspects for Understanding Mathemathics Teachers at MTs Al Mustaqim Parepare". Based on the background, then the formulation of the problem in this research is: How does the Description of Difficulties in Implementing the Assesment of Performance Aspects for Understanding Mathemathic Teachers at MTs Al Mustaqim Parepare?

\section{RESEARCH METHOD}

The type of research is descriptive research with a qualitative approach (Sangadji, 2010). The aims for a description of the difficulty of implementing performance assessment on aspects of mathematics teachers' understanding of MTs Al Mustaqim Pare Pare, the subjects in this research certainly is a mathematic teachers.

The main instrument in this research was "the researcher itself ", because the researcher are planners, implementers, data collectors, analyzers, the interpreter of data, 
and the reporting of research results. In this research also used other supporting instruments such as comprehension tests and guidelines for the interview.

\section{RESULT AND DISCUSSION}

\section{Research Result}

The description of the teacher answers is obtained through comprehension tests and an interview for each subjects of research can be explained as follows:

1. Subject $1(\mathrm{H})$

The results of the data analysis related to the understanding of teachers about performance assessment then it can be summarized. Those are (1) Subject $1(\mathrm{H})$ did not know the definition of assessment itself. (2) Subject $1(\mathrm{H})$ did not know the selfassessment that it is not the technique assessment so that it can apply to assess the competence of the skills for students. (3) Subject $1(\mathrm{H})$ determined the benefits in the implementation of performance assessment. (4) Subject $1(\mathrm{H})$ knew the instruments using in the assessment of their performance. (5) Subject $1(\mathrm{H})$ did not know what does it mean of the analytical section. (6) Subject $1(\mathrm{H})$ determined the forms of performance a student that can be an implementation of performance assessment. (7) Subject $1(\mathrm{H})$ knew the benefits of performance assessment in mathematic.

Furthermore, it found interesting findings on the data subject 1, which is the subject $1(\mathrm{H})$ applied the performance assessment that did not know about the assessment of the performance but because of the demands of the curriculum in 2013 which required it to conduct authentic assessment that one of them can do with a performance assessment. It admitted also by the subject $1(\mathrm{H})$ that he less read reference on performance assessment so that his understanding of the performance assessment was still lack.

Based on the analysis, it can be concluded that the understanding of the subject 1 (H) related to performance assessment was still lack because this was due to lack of reading references. As for the difficulty for the subject $1(\mathrm{H})$ of understanding aspects related to the assessment of performance as follows:

1. Subject $1(\mathrm{H})$ was difficult in understanding the concept of assessment.

2. Subject $1(\mathrm{H})$ was difficult in understanding the assessment techniques that can be applied to assess the competence skills of students.

3. Subject $1(\mathrm{H})$ was difficult in understanding the types of assessment rubric.

\section{Subject $2(\mathrm{~N})$}

The result of the data analysis related to the understanding of teachers performance assessment can be summarized as follows: (1) Subject 2 (N) did not know the definition of assessment. (2) Subject 2 (N) knew of valuation techniques 
that can be applied by teachers to assess students' competency skills. (3) Subject 2 (N) knew the benefits that can be gained in the implementation of performance assessment. (4) Subject 2 (N) knew the instruments to use in the assessment of their performance. (5) Subject $2(\mathrm{~N})$ determined the criteria of a good instrument performance. (6) Subject 2 (N) knows the purpose of the analytical section. (7) Subject $2(\mathrm{~N})$ knew the shapes of performance to the students in the implementation of performance assessment. (8) Subject 2 (N) knew the benefits of performance assessment in mathematics.

Furthermore, it found that it interests findings on the data subject 2 . Where the interesting findings is obtained by researchers through interviewing the subject $2(\mathrm{~N})$ implementing performance assessment of this because researcher think by implementing performance assessment will have many benefits that can be gained of which can enhance the creativity of students, less of student's chances for cheating, and very good to assess the skills of students. In addition, subject 2 (N) somewhat out of the performance assessment for his reference, and a willingness to learn, read, attend the training and workshops.

Based on the above data analysis, it can be concluded that the subject $2(\mathrm{~N})$ had a good understanding of performance assessment, for their references and a willingness to learn, read, attend the training and workshops. The difficulties experienced subject $2(\mathrm{~N})$ in terms of understanding related to the assessment of performance was the subject of $2(\mathrm{~N})$ had difficulty in understanding the concept of assessment.

\section{Discussion}

There were many techniques for the teachers' assessment in learning aspect or competence and it will be assessed by the teacher in the learning process. One of the assessment techniques that can be applied by teachers to assess aspects of students' skills or competencies were performance assessment or performance appraisal. Based on the Permendikbud No. 66 in 2013 explained that educators assess the competence skills through performance assessment, such as the assessment requires students to demonstrate a certain competence by using the practice test, project, and portfolio assessment. Therefore, teachers who want to implement a performance assessment; teachers should have a good knowledge or understanding of the performance assessment. We cannot deny that one of the factors that can ensure the implementation of a good performance appraisal it based on the understanding that a good teacher is also related to performance assessment. It is just that we cannot deny; there were many teachers still lack for understanding about the concept of assessment itself.

Based on the analysis tests the understanding of teachers, which is reinforced by interviews in this study, it indicates that the subjects in this study had a different understanding related to the assessment of performance. As for the difficulty of the subject $1(\mathrm{H})$ related to understanding performance ratings as follows: 


\section{CONCLUTION}

The result research shows that the difficulties for teachers, it is for understanding aspect about the assessment performance. For instance, (a) the subject $1(\mathrm{H})$ was difficult in understanding about the concept of assessment, (b) the subject $1(\mathrm{H})$ was difficult in understanding the assessment techniques so that it can be implemented, (c) subject $1(\mathrm{H})$ was difficult in understanding the types of assessment rubrics, and (d) subject 2 (N) was difficult in understanding the concept of assessment.

\section{REFERENCES}

Abidin, Jonah. (2014). Design of Learning Systems in the Context of Curriculum 2013 . .Bandung: RefikaAditama.

Majid, Abdul. Authentic Assessment Process and Learning Outcomes . Bandung: PT. Youth Rosdakarya.

Meutia, Hifzi.,Johar, Rahmah. \& Ahmad, Anizar. 2013. Ability Prospective Students Teachers Implementing Performance Assessment for Assessing Student Learning Outcomes in Mathematics Learning . Opportunities available on the Journal Vol. 1 No. 2.

Sangadji, Etta MamangdanSopiah. (2010). MetodologiPenelitianPendekatanPraktisdalam Penelitian. Yogyakarta: Andi. 